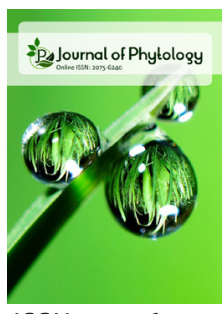

ISSN: $2075-6240$

\title{
Evaluation of treated wastewater irrigation on the productivity of wheat
}

\author{
Fatima Hasan Al Hamedi, Kandhan Karthishwaran, Mohammed A. Salem* \\ Department of Integrative Agriculture, College of Food and Agriculture, PO Box No. 15551, United Arab Emirates \\ University, Al Ain, UAE
}

\begin{abstract}
The major objective of this research work is to propose the initial environmental impact assessment concerning the utilization of treated wastewater for two different varieties of wheat production. The study analyzed the soil chemical composition before and after irrigation at two different depths $(0-30 \mathrm{~cm} \& 30-60 \mathrm{~cm})$. Water chemical composition is also analyzed for controlled water, treated water of Abu Dhabi and Al Ain. Wheat plant chemical composition present in the head, root, and shoot for both the varieties is analyzed. The levels of $\mathrm{Ca}, \mathrm{Mg}, \mathrm{Na}$ and $\mathrm{CI}$ in soil have increased after irrigation with controlled water. The presence of cations and anions in the soil are slightly higher in the treated water of Abu Dhabi. Ca, Na, CI and $\mathrm{SO}_{4}$ are found to be significantly higher after irrigation with treated wastewater of $\mathrm{Al}$ Ain. The plant chemical composition of head, root and shoot ND fiber, AD fiber, Crude protein and Macro elements have shown no significant differences across the three types of water and two varieties of wheat production. The correlations between RBS limits and the three types of water considered in the study are negative. The results revealed that the differences in chemical composition between RBS limits, controlled, treated wastewater of Abu Dhabi and $\mathrm{Al}$ Ain are statistically significant with particular reference to trace and heavy metals. Concerning water chemical composition, the study concludes that the correlation between controlled water and treated wastewater of $\mathrm{Al}$ Ain is strong when compared to Abu Dhabi.
\end{abstract}

Received: August 01, 2020 Revised: September 22, 2020 Accepted: September 30, 2020 Published: October 07, 2020

Corresponding Author: Mohammed A. Salem

Email:mohammed.s@uaeu.ac.ae KEYWORDS: Climate change, wheat crop, wastewater, fiber, elements

\section{INTRODUCTION}

Climate conditions around the globe face a variety of problems, including water shortages in many nations. Climate change greatly affects the balance of demand and the availability of natural resources in many ways. Growth in population, socioeconomic impacts are having an effect on water supplies in the Arab region. Climate change and climate instability bring more complexities. Increased temperatures can lead to rapid evaporating water throughout the Arab region, including the UAE. [1]. Ensuring the optimal supply of water for drinking, agriculture and other uses has truly become a challenge. Reuse of wastewater can be an effective response to water scarcity by implementing the concepts of integrated water management[2].

Wastewater use in agriculture without the appropriate precautions can influence the accumulation of microbiological and chemical pollutants in crops and soil conditions. Interestingly, urban wastewater has the largest share of wastewater used for agricultural purposes, as it can lead to better crop nutrition. Municipal wastewater use for agricultural purposes is a common practice in the MENA region. [3]. While treated wastewater is a cheap resource that is accessible all year round, it has many hazards if not handled properly. Wastewater and treated wastewater have become viable and effective water supplies that can complement the freshwater resources of a nation. By 2050, urban areas will grow dramatically and about $70 \%$ of the world's population is projected to reside in cities that ensure reliable wastewater supply [4]. However, it is vital to use wastewater for irrigation by safeguarding the health of important stakeholders, such as farmers and customers at large, while mitigating negative environmental impacts.

There are a number of restrictions on the treatment and re-use of treated wastewater in agriculture, including insufficient knowledge on the environmental and health effects of reuse, limited economic analysis, including financial viability and government-benefits, government participation in the processing and treatment of wastewater [5]. Analysis of the benefits and associated risks associated with the use of treated wastewater has shown that not only are soil health conditions economic but also increased, while at the same time reducing fertilizer requirements. It is important to understand that salts, nitrogen and bacteria are the major sources of risk

Copyright: $\odot$ The authors. This article is open access and licensed under the terms of the Creative Commons Attribution License (http://creativecommons.org/licenses/by/4.0/) which permits unrestricted, use, distribution and reproduction in any medium, or format for any purpose, even commercially provided the work is properly cited. Attribution - You must give appropriate credit, provide a link to the license, and indicate if changes were made. 
associated with the use of recycled water for irrigation and, surprisingly, the risks associated with heavy metals are relatively low [6]. The main purpose of this research paper is to suggest an initial environmental impact assessment with respect to the use of treated wastewater for wheat production. The research involves an analysis of the chemical composition of the wheat plant present in the head, root and shoot of two varieties of wheat.

\section{MATERIALS AND METHODS}

Two varieties of wheat were cultivated using three different types of water, such as freshwater Controlled (C), Abu Dhabi Treated Wastewater (T1) and Al Ain Treated Wastewater (T2). The experiments were performed at the Al-Foah Research Farm of UAE University located in Al Ain City, UAE. The experiments were performed during the rising season between November to March. A surface area of $318 \mathrm{~m}^{2}(20.5 \mathrm{~m} \times 15.5 \mathrm{~m})$ was used to carry out the experiments. Five replications were made for each form of wheat within a plot area of $2 \times 2.5 \mathrm{~m}^{2}$ using three separate water treatments. Drip irrigation system has been used for all water treatments. Chemical fertilizers were used once a week by irrigation at rates of $200 \mathrm{~kg} \mathrm{~N} / \mathrm{ha}, 120 \mathrm{~kg} \mathrm{P}_{2} \mathrm{O}_{5} / \mathrm{ha}$ and $80 \mathrm{~kg} \mathrm{~K}_{2} \mathrm{O} / \mathrm{ha}$.

Two different treated wastewater (TWW) from Al Wathba, Abu Dhabi and Al SAAD, Al Ain were used for experimental water. Normal local well water was used as control. The experimental plan used was factorial based and completely randomised. Wheat seeds were germinated for 10 days, and then 13 seedlings were transplanted into each pot.

\section{Crop and Management}

Two different genotypic advanced lines derived from the international trial $33^{\text {rd }}$ ESWYT (V1) and 20 ${ }^{\text {th }}$ SAWYT (V2) were used as targets for this research and these wheat varieties were obtained from the CIMMYT Genetic Resource Centre, El Batan, Mexico. Temperature, $\mathrm{pH}$, and $\mathrm{EC}$ of the different kinds of water were monitored using combined portable $\mathrm{pH} / \mathrm{EC} / \mathrm{TDS} /$ Temperature meter (Hanna instrument, USA).

\section{Analysis of Agronomical Parameters}

After 12 weeks of planting, wheat plant samples were harvested to evaluate the agronomical parameters such us plant length, root length, plant weight, dry weight, flag length and area, number of heads and head length.

\section{Estimation of Crude Protein}

The Kjeldahl method was followed by the AOAC International [7] method. Approximately $1 \mathrm{~g}$ of raw material was hydrolyzed with $15 \mathrm{~mL}$ of $\mathrm{H}_{2} \mathrm{SO}_{4}$ containing two copper catalytic tablets in a heat of $420^{\circ} \mathrm{C}$ for 2 hours. After cooling, $50 \mathrm{ml}$ of 4 percent boric acid solution in the receiving flask added 3-5 drops of the mixed indicator and placed it under the Kjeldahl condenser. The distillation machine ensures that the condenser tube reaches below the acid surface in the flask and now applies $50 \mathrm{ml}$ of water and $60 \mathrm{ml}$ of $32 \%$ of $\mathrm{NaOH}$ solution to the Kjeldahl flask. Take $0.1 \mathrm{~N} \mathrm{HCl}$ in the burette and titrate the contents of the flask against it.

\section{Procedure for NDF Determination (Neutral detergent fiber)}

The content of neutral detergent fiber was calculated by the Waldern [8] process. $1 \mathrm{~g}$ of fine powder was weighed in a crucible and $100 \mathrm{ml}$ of neutral detergent solution, $0.5 \mathrm{~g}$ of sodium sulphite and a few drops of n-octanol were added. The reaction mixture was purified and the extract was washed three times with hot water and two times with acetone. The resulting mixture was allowed to stand dry for 8 hours incubated at $105^{\circ}$ $\mathrm{C}$ and then in a desiccator.

\section{Acid detergent Fiber}

The content of acid detergent fiber was calculated by the Dong and Rasco [9] process. Exactly $1 \mathrm{~g}$ of fine powder was weighed in a crucible and $100 \mathrm{ml}$ of acid detergent solution and a few drops of n-octanol were added. The reaction mixture was allowed to stand for 60 minutes in boiling conditions. The reaction mixture was filtered and the extract was washed with hot water for three times and acetone for two times. The resulting mixture was permitted to stand dry for 8 hours incubated at $105^{\circ} \mathrm{C}$ and then in a desiccator. Weight of the content was articulated in gms.

\section{Microelements and Macroelements}

Mineral elements were measured in the dry head, shoot and root tissue at the end of the harvest. The samples were airdried then oven-dried at $105^{\circ} \mathrm{C}$ for 3 hours and the samples were grinded and deposited in the desiccators for further analysis. Samples were appropriately prepared by measuring 0.5 grams of sample in microwave digestion vessels and adding $10 \mathrm{ml}$ of concentrated nitric acid $\left(\mathrm{HNO}_{3}\right)$ and $2 \mathrm{ml}$ of hydrochloric acid (HCL) [10]. The vessels were capped and place in the microwave digestion system. The analysis was conducted using ICP-OES - Agilent Technologies, 710ES - Agilent Technologies. The percentages of different elements in this sample was determined by the corresponding standard calibration curves obtained by using standard AR grade solutions of the elements, for example $\mathrm{K}, \mathrm{Mg}, \mathrm{Ca}, \mathrm{Na}$, $\mathrm{Fe}, \mathrm{Mn}, \mathrm{Zn}, \mathrm{P}$ and $\mathrm{S}$. The blank reagents were carried out using the complete procedure and contain the same acid concentration in the final solution as the sample solution used for the investigation.

\section{Statistical Analysis}

Statistical analysis was performed using one way analysis of variance followed by Duncan's Multiple Range Test using Statistical Package for the Social Science software (SPSS) 
package version 12.00. Results were expressed as mean \pm standard deviation for six replicates in each group. P values $<0.05$ were considered statistically significant.

\section{RESULT AND DISCUSSION}

\section{Treated Wastewater Chemical Composition}

In the current analysis, it was examined whether the treated wastewater chemical composition is within an appropriate safety range after irrigation with treated wastewater and the results were obtained in Table l. The AD (T1) sample of water used for irrigation showed an acidic $\mathrm{pH}$ value of $4.93 \pm 0.28$. Most plant tissues remain in active growth at a $\mathrm{pH}$ above seven [11]. The optimum $\mathrm{pH}$ of irrigation water approved by FAO is between 6.0 and 8.5 . As can be seen from the $\mathrm{pH}$ calculation, the result indicates the existence of optimum $\mathrm{pH}$ values in the control and AA (T2) water samples. Based on the FAO guidelines, the $\mathrm{pH}$ of $\mathrm{AD}(\mathrm{Tl})$ used in this study did not follow the limits set by FAO [12]. The other two samples control and AA (T2) are therefore ideal for irrigation. The use of high electrical conductivity (EC) effluents has some negative effects in that crops grown in a high EC medium may be characterized by the observation of the consumption of less ions resulting in poor growth [13]. The ideal EC values for waste water used for irrigation as set out in EPP (1995) were $<0.8 \mathrm{~m} \mathrm{~S} / \mathrm{cm}$. Wilcox [14] used the following table as an arbitrary guide to the quality of irrigation water based on EC principles. The mean mean $\mathrm{EC}$ value of $\mathrm{AA}(\mathrm{T} 2)$ was $0.95 \pm .05 \mathrm{mS} / \mathrm{cm}$. This confirms that it is appropriate for irrigation as it reaches the ideal limit range of $0-3.0(\mathrm{ds} / \mathrm{m})$.

The higher the electrical conductivity of the hydroponics medium, the higher the negative effects of $\mathrm{Na} \mathrm{Cl}$ on crops [15]. The explanation for this is that the crops grown in AA (T2) effluent were less active than AD (T1) and control (Table 1). This is hazardous to reuse treated AA (T2) water in agriculture as it has high concentrations of potassium [16]. Two essential elements such as sodium and chlorine in excess concentration can harm the plants by reducing the absorption of potassium [17]. The acceptable limits of sodium and chloride values in treated water used for irrigation are $<40$ and $<30$ $\mathrm{mg} / \mathrm{L}$ respectively. The elements of calcium $(\mathrm{Ca})$ and Boron (B) are present within safe limits compared to FAO standards. The recommended values of $\mathrm{Ca}$ and $\mathrm{B}$ set by $\mathrm{FAO}$ are $<400$ Ppm, and $<2.0 \mathrm{mg} / \mathrm{L}$ respectively. Previous literatures reported that high calcium is needed for optimum root growth of barley and cotton. The presence of ideal concentrations of sulphate, strontium $(\mathrm{Sr})$, iron $(\mathrm{Fe})$, nickel $(\mathrm{Ni})$ Barium $(\mathrm{Ba})$, and selenium (Se) justifies the efficiency of treated waste water in crop production [18].

Karl Pearson's Co-efficient of association between the three water varieties and the RBS limits has been determined and the results are shown in Table 2 . The results indicate that the correlation between well (controlled) and treated water (T2) $\mathrm{Al}$ Ain is important, while the correlation between treated wastewater (T2) Al Ain and treated wastewater (T1) Abu Dhabi is moderate, and the correlations between the RBS

Table 1: Cations, anions, trace and heavy metals present in three types of water

\begin{tabular}{|c|c|c|c|c|}
\hline Parameters & Control & Treated AD (T1) & Trated AA (T2) & Acceptable limits \\
\hline $\mathrm{pH}$ & $7.53 \pm 0.31$ & $7.40 \pm 0.28$ & $7.60 \pm 0.53$ & $6.0-8.5$ \\
\hline $\mathrm{EC}(\mathrm{ds} / \mathrm{m})$ & $0.31 \pm 0.05$ & $0.33 \pm 0.05 b$ & $0.35 \pm .05$ & $0-.3 .0$ \\
\hline TDS ppm & $211.40 \pm 32.45$ & $212.40 \pm 21.25$ & $220.11 \pm 3.41$ & $<2000$ \\
\hline SAR & $2.23 \pm 0.45$ & $2.23 \pm 0.45$ & $3.19 \pm 0.52$ & 41.25 \\
\hline Total N & $3.83 \pm 14.80$ & $2.63 \pm 4.81$ & $2.30 \pm 0.19$ & $<5 \mathrm{mg} / \mathrm{L}$ \\
\hline Nitrate N03 & $0.00 \pm .00$ & $9.46 \pm 1.74$ & $7.363 \pm 0.84$ & $0-10.0 \mathrm{mg} / \mathrm{L}$ \\
\hline Calcium (Ca) mg/L & $17.94 \pm 1.70$ & $17.94 \pm 1.70$ & $15.94 \pm 2.01$ & $0-20.0$ \\
\hline Magnesium (Mg)mg/L & $2.62 \pm 0.50$ & $2.62 \pm 0.50$ & $3.26 \pm 0.25$ & $0-5.0$ \\
\hline Sodium (Na)mg/L & $41.28 \pm 4.95$ & $41.78 \pm 0.24$ & $40.19 \pm 9.21$ & $0-40.0$ \\
\hline Potassium (K)mg/L & $1.74 \pm 0.45$ & $1.84 \pm 0.04$ & $1.2 \pm 0.24$ & $<2.0$ \\
\hline Chloride (Cl)mg/L & $25.85 \pm 22.17$ & $29.81 \pm 0.24$ & $25 \pm 10.2$ & $0-30.0$ \\
\hline Carbon trioxide $\left(\mathrm{CO}_{3}\right)$ & - & - & - & NA \\
\hline Sulphate $\left(\mathrm{SO}_{4}\right) \mathrm{mg} / \mathrm{L}$ & $4.32 \pm 0.14$ & $4.32 \pm 0.27$ & $5.51 \pm 6.24$ & $0-20.0$ \\
\hline Phosphate $\left(\mathrm{PO}_{4}\right) \mathrm{mg} / \mathrm{L}$ & $0.31 \pm 0.02$ & $0.31 \pm 0.14$ & $0.31 \pm 0.02$ & $<2.0$ \\
\hline Aluminium (Al) mg/L & $0.10 \pm 0.04$ & $0.10 \pm 0.01$ & $0.13 \pm 0.23$ & 5.0 \\
\hline Arsenic (As) mg/L & $0.08 \pm 0.01$ & $0.07 \pm 0.01$ & $0.06 \pm 0.05$ & 0.10 \\
\hline Boron (B)mg/L & $0.26 \pm 0.06$ & $0.26 \pm 0.01$ & & $0-2.0$ \\
\hline Barium (Ba) & - & - & $0.01 \pm 0.00$ & - \\
\hline Cadmium (Cd) & - & - & - & $<0.01$ \\
\hline Cobalt (Co)mg/L & - & - & - & 0.05 \\
\hline Copper (Cu) & $0.01 \pm 0.01$ & $0.01 \pm 0.00$ & $0.00 \pm 0.00$ & $0.05-0.3$ \\
\hline Iron (Fe) mg/L & - & - & - & 20 \\
\hline Manganese $(\mathrm{Mn}) \mathrm{mg} / \mathrm{L}$ & $0.01 \pm 0.01$ & $0.01 \pm 0.001$ & $0.01 \pm 0.00$ & $0.2-10.0$ \\
\hline Molybdenum (Mo) & $0.02 \pm 0.02$ & $0.03 \pm 0.003$ & $0.02 \pm 0.01$ & $0.01-0.05$ \\
\hline Nickel (Ni) mg/L & - & & $0.08 \pm 0.00$ & $<0.2$ \\
\hline Lead (Pb) mg/L & $0.02 \pm 0.01$ & $0.02 \pm 0.001$ & $0.03 \pm 0.00$ & $<2$ \\
\hline Selenium (Se)mg/L & $0.18 \pm 0.01$ & $0.18 \pm 0.01$ & $0.15 \pm 0.00$ & 0.02 \\
\hline Strontium (Sr) & $0.01 \pm 0.02$ & $0.01 \pm 0.001$ & $0.08 \pm 0.01$ & - \\
\hline Zinc $(Z n)$ & $0.19 \pm 0.08$ & $0.19 \pm 0.002$ & $0.02 \pm 0.01$ & $0.1-0.5$ \\
\hline $\mathrm{pH}$ & $7.53 \pm 0.31$ & $7.40 \pm 0.28$ & $7.60 \pm 0.53$ & $6.0-8.5$ \\
\hline
\end{tabular}


limits and three types of water vz., regulated, T1 and T2 are negative. Since the P-value (0.0060) of the ANOVA test performed at a 5 percent significance level is less than 0.5 and thus the discrepancy between the RBS limits, well, the Tl and $\mathrm{T} 2$ values obtained are statistically relevant on the basis of which it can be inferred that there is a substantial difference between RBS and well, $\mathrm{Tl}$ and $\mathrm{T} 2$ with respect to trace metals and heavy metals.

\section{Plant Chemical Composition}

The percentage of N.D fiber, A.D fiber, crude protein, macro elements, Sec elements, trace elements and heavy metals present in the wheat plant 's head, root and shoot have been investigated at all three sites for both the wheat varieties considered for the analysis (Tables 3-5). The essential elements affect the nutritional value of edible plants is their fiber and protein content. Daniz et al. [19] reported that the ADF content increased because of progress towards the grain-filling age, but cultivars may have different reactions. In our research, however, the ADF content was increased along with plant growth, as was the case with most cultivated crops.

Table 2: Correlation matrix for three varieties of water and RBS limits

\begin{tabular}{lcccc}
\hline Parameters & $\begin{array}{c}\text { Well } \\
\text { (Controlled) }\end{array}$ & $\begin{array}{c}\text { Treated (T1) } \\
\text { Abu Dhabi }\end{array}$ & $\begin{array}{c}\text { Treated (T2) } \\
\text { Al Ain }\end{array}$ & $\begin{array}{c}\text { RSB } \\
\text { limits }\end{array}$ \\
\hline Well (Controlled) & 1 & & & \\
Treated (T1) Abu Dhabi & 0.10523 & 1 & & \\
Treated (T2) Al Ain & 0.771584 & 0.510581 & 1 & \\
RBS limits & -0.00521 & -0.00476 & -0.01687 & 1 \\
\hline
\end{tabular}

Nutritional composition has been observed that there is a great diversity of elemental contents studied in different parts of the wheat crop. Results of the elemental analysis obtained via the comparator process of the AAS techniques are seen in the results of the samples' $\mathrm{mg} / \mathrm{g}$ dry weight. It should be noted that each result is an average of at least three independent measurements with accuracy of approximately $\pm 1 \%$. For most studies, the protein content is regarded as the key determinant of the form of food and less is known about the elemental composition of different wild edible organisms. As shown in the results, compared with the normal prescribed dietary allowance, the content of microelements in both variety and nutritional significance of the product.

The recommended protein dietary allowance (RDA) is $56 \mathrm{~g}$ for persons weighing $70 \mathrm{~kg}$ and $46 \mathrm{~g}$ for adults weighing $50 \mathrm{~kg}$; children may consume $2 \mathrm{~kg} /$ day [20]. According to Pamela et al. [21], plant-based proteins are of lower quality but their combination with many other protein sources such as animal protein can result in an adequate nutritional value. The concentrations of fibers and elements for plant products were found almost in line with the World Health Organizations standards [22].

The yields of plants like wheat were significantly higher when irrigated with treated wastewater compared with the use of saline well water. The increase in yield can mainly be attributed to plants obtaining 20 per cent higher water due to increased nitrogen supply while reducing the salinity level in their roots. In addition, water efficiency achieved at higher levels in plants receiving treated wastewater at an ETM level of 120

Table 3: Fiber, protein, macro and secondary elements present in both the varieties of wheat plant head

\begin{tabular}{|c|c|c|c|c|c|c|}
\hline \multirow[t]{2}{*}{ Parameters } & \multicolumn{6}{|c|}{ Plant head sample } \\
\hline & CV1 & CV2 & TIVI & T1 V2 & T2V1 & T2V2 \\
\hline N.D.F & $57.22 \pm 6.74$ & $67.51 \pm 2.89$ & $55.32 \pm 7.74$ & $59.81 \pm 2.12$ & $52.22 \pm 5.03$ & $58.92 \pm 7.31$ \\
\hline A.D.F & $29.94 \pm 2.93$ & $33.63 \pm 0.68$ & $29.33 \pm 3.95$ & $27.88 \pm 2.63$ & $28.70 \pm 3.33$ & $29.57 \pm 3.56$ \\
\hline Crude Protein\%" & $10.72 \pm 0.97$ & $10.27 \pm 0.32$ & $13.22 \pm 3.58$ & $12.33 \pm 2.70$ & $9.96 \pm 0.78$ & $10.20 \pm 0.99$ \\
\hline $\mathrm{N}$ & $1.72 \pm 0.16$ & $1.64 \pm 0.05$ & $2.12 \pm 0.57$ & $1.97 \pm 0.43$ & $1.59 \pm 0.12$ & $1.63 \pm 0.16$ \\
\hline$P$ & $0.50 \pm 0.02$ & $0.53 \pm 0.02$ & $0.49 \pm 0.04$ & $0.49 \pm 0.03$ & $0.45 \pm 0.03$ & $0.51 \pm 0.06$ \\
\hline k & $0.94 \pm 0.13$ & $1.05 \pm 0.09$ & $0.98 \pm 0.14$ & $1.06 \pm 0.13$ & $0.83 \pm 0.13$ & $0.97 \pm 0.16$ \\
\hline $\mathrm{Ca}$ & $0.25 \pm 0.03$ & $0.21 \pm 0.02$ & $0.24 \pm 0.03$ & $0.21 \pm 0.01$ & $0.23 \pm 0.01$ & $0.22 \pm 0.01$ \\
\hline Mg & $0.24 \pm 0.02$ & $0.20 \pm 0.02$ & $0.24 \pm 0.03$ & $0.22 \pm 0.02$ & $0.24 \pm 0.02$ & $0.23 \pm 0.02$ \\
\hline S & $0.19 \pm 0.02$ & $0.43 \pm 0.52$ & $0.20 \pm 0.02$ & $0.27 \pm 0.17$ & $0.20 \pm 0.01$ & $0.20 \pm 0.01$ \\
\hline $\mathrm{Na}$ & $0.03 \pm 0.00$ & $0.03 \pm 0.02$ & $0.04 \pm 0.01$ & $0.05 \pm 0.02$ & $0.03 \pm 0.00$ & $0.03 \pm 0.00$ \\
\hline $\mathrm{Fe}$ & $105.20 \pm 56.33$ & $63.60 \pm 15.88$ & $80.60 \pm 17.90$ & $72.80 \pm 22.51$ & $73.20 \pm 18.05$ & $71.20 \pm 12.97$ \\
\hline $\mathrm{Cu}$ & $180.96 \pm 73.95$ & $133.77 \pm 32.87$ & $159.18 \pm 40.19$ & $125.91 \pm 34.39$ & $130.11 \pm 24.74$ & $129.40 \pm 26.36$ \\
\hline $\mathrm{Mn}$ & $5.52 \pm 0.93$ & $6.50 \pm 1.96$ & $3.50 \pm 0.46$ & $3.12 \pm 0.31$ & $4.50 \pm 0.49$ & $4.16 \pm 0.69$ \\
\hline Zn & $20.80 \pm 2.90$ & $13.98 \pm 1.48$ & $20.92 \pm 3.90$ & $12.82 \pm 5.08$ & $22.52 \pm 1.62$ & $21.52 \pm 4.01$ \\
\hline B & $55.52 \pm 5.13$ & $47.90 \pm 1.86$ & $54.06 \pm 5.99$ & $48.14 \pm 4.69$ & $61.92 \pm 6.16$ & $52.84 \pm 3.02$ \\
\hline Mo & $64.33 \pm 83.31$ & $35.60 \pm 6.98$ & $33.49 \pm 6.82$ & $30.72 \pm 5.15$ & $30.00 \pm 9.33$ & $34.84 \pm 9.33$ \\
\hline $\mathrm{Ni}$ & $0.10 \pm 0.22$ & $0.00 \pm 0.00$ & $0.98 \pm 1.92$ & $0.12 \pm 0.27$ & $0.00 \pm 0.00$ & $0.34 \pm 0.71$ \\
\hline $\mathrm{Pb}$ & $4.17 \pm 3.30$ & $2.90 \pm 1.61$ & $2.31 \pm 0.67$ & $1.58 \pm 0.72$ & $2.49 \pm 0.42$ & $5.88 \pm 5.05$ \\
\hline $\mathrm{Sr}$ & $1.18 \pm 1.24$ & $1.60 \pm 1.03$ & $2.08 \pm 0.99$ & $2.14 \pm 1.49$ & $1.26 \pm 0.76$ & $1.14 \pm 0.54$ \\
\hline Al & $33.40 \pm 2.79$ & $32.20 \pm 6.14$ & $28.20 \pm 3.70$ & $26.80 \pm 2.17$ & $30.80 \pm 2.05$ & $32.40 \pm 7.37$ \\
\hline $\mathrm{Ba}$ & $15.24 \pm 1.13$ & $14.12 \pm 4.37$ & $8.45 \pm 1.99$ & $7.01 \pm 1.20$ & $13.05 \pm 2.13$ & $12.96 \pm 3.59$ \\
\hline $\mathrm{Cd}$ & $0.15 \pm 0.21$ & $0.24 \pm 0.19$ & $0.41 \pm 0.25$ & $0.34 \pm 0.20$ & $0.18 \pm 0.14$ & $0.27 \pm 0.06$ \\
\hline Co & $0.17 \pm 0.17$ & $0.11 \pm 0.15$ & $0.24 \pm 0.19$ & $0.13 \pm 0.22$ & $0.09 \pm 0.12$ & $0.06 \pm 0.10$ \\
\hline $\mathrm{Cr}$ & $1.59 \pm 0.50$ & $1.34 \pm 0.28$ & $1.68 \pm 0.64$ & $1.20 \pm 0.45$ & $1.79 \pm 0.46$ & $1.21 \pm 0.44$ \\
\hline Se & $0.00 \pm 0.00$ & $0.00 \pm 0.00$ & $0.00 \pm 0.00$ & $0.00 \pm 0.00$ & $0.00 \pm 0.00$ & $0.00 \pm 0.00$ \\
\hline
\end{tabular}

Data are averages of five replicates, with SD values $(n=5)$. ADF, acid detergent fiber; NDF, neutral detergent fiber 
Table 4: Fiber, protein, macro and secondary elements present in root

\begin{tabular}{|c|c|c|c|c|c|c|}
\hline \multirow[t]{2}{*}{ Parameters } & \multicolumn{6}{|c|}{ Plant root sample } \\
\hline & CVI & CV2 & TIV1 & $\mathrm{T} 1 \mathrm{~V} 2$ & T2V1 & $\mathrm{T} 2 \mathrm{~V} 2$ \\
\hline N.DF & $76.65 \pm 1.80$ & $73.00 \pm 7.69$ & $67.57 \pm 8.98$ & $69.09 \pm 7.77$ & $69.30 \pm 10.28$ & $73.98 \pm 2.07$ \\
\hline A.D.F & $51.23 \pm 2.33$ & $52.00 \pm 1.53$ & $49.24 \pm 2.12$ & $48.88 \pm 2.81$ & $51.31 \pm 1.24$ & $49.79 \pm 2.87$ \\
\hline Crude Protein\%" & $2.18 \pm 0.98$ & $1.75 \pm 1.10$ & $4.10 \pm 0.78$ & $4.09 \pm 0.69$ & $2.99 \pm 0.93$ & $3.23 \pm 1.05$ \\
\hline $\mathrm{N}$ & $0.35 \pm 0.16$ & $0.28 \pm 0.17$ & $0.66 \pm 0.12$ & $0.65 \pm 0.11$ & $0.48 \pm 0.15$ & $0.52 \pm 0.17$ \\
\hline$P$ & $0.12 \pm 0.04$ & $0.10 \pm 0.03$ & $0.17 \pm 0.06$ & $0.15 \pm 0.05$ & $0.11 \pm 0.01$ & $0.14 \pm 0.05$ \\
\hline k & $0.59 \pm 0.15$ & $0.49 \pm 0.16$ & $0.60 \pm 0.09$ & $0.51 \pm 0.10$ & $0.64 \pm 0.18$ & $0.64 \pm 0.27$ \\
\hline $\mathrm{Ca}$ & $2.74 \pm 0.55$ & $3.20 \pm 0.81$ & $2.25 \pm 0.32$ & $2.39 \pm 0.49$ & $3.16 \pm 0.74$ & $2.92 \pm 0.84$ \\
\hline $\mathrm{Mg}$ & $1.62 \pm 0.30$ & $1.90 \pm 0.42$ & $1.25 \pm 0.21$ & $1.49 \pm 0.26$ & $1.77 \pm 0.33$ & $1.68 \pm 0.52$ \\
\hline S & $0.10 \pm 0.02$ & $0.11 \pm 0.02$ & $0.21 \pm 0.05$ & $0.33 \pm 0.33$ & $0.19 \pm 0.10$ & $0.18 \pm 0.08$ \\
\hline $\mathrm{Na}$ & $0.12 \pm 0.03$ & $0.10 \pm 0.03$ & $0.59 \pm 0.27$ & $0.58 \pm 0.11$ & $0.19 \pm 0.07$ & $0.27 \pm 0.10$ \\
\hline $\mathrm{Fe}$ & $5189.00 \pm 1269.18$ & $5773.80 \pm 847.21$ & $4180.60 \pm 992.52$ & $4988.60 \pm 1142.89$ & $6132.00 \pm 888.13$ & $5041.60 \pm 1412.17$ \\
\hline $\mathrm{Cu}$ & $8.54 \pm 2.29$ & $9.00 \pm 1.91$ & $6.92 \pm 1.00$ & $6.81 \pm 0.51$ & $6.61 \pm 0.63$ & $6.74 \pm 1.05$ \\
\hline $\mathrm{Mn}$ & $113.38 \pm 30.85$ & $130.88 \pm 17.88$ & $98.24 \pm 15.21$ & $104.68 \pm 16.20$ & $129.34 \pm 22.83$ & $121.14 \pm 29.78$ \\
\hline $\mathrm{Zn}$ & $47.08 \pm 8.79$ & $39.68 \pm 9.74$ & $72.30 \pm 20.90$ & $59.96 \pm 24.34$ & $59.58 \pm 18.74$ & $59.22 \pm 19.80$ \\
\hline B & $37.34 \pm 1.62$ & $30.32 \pm 3.59$ & $45.82 \pm 9.35$ & $39.06 \pm 6.31$ & $34.96 \pm 3.62$ & $36.54 \pm 4.74$ \\
\hline Mo & $0.97 \pm 0.91$ & $0.69 \pm 0.55$ & $1.92 \pm 1.02$ & $0.94 \pm 1.55$ & $0.51 \pm 0.74$ & $1.25 \pm 1.29$ \\
\hline $\mathrm{Ni}$ & $168.96 \pm 43.25$ & $198.18 \pm 42.64$ & $127.84 \pm 28.41$ & $148.66 \pm 40.23$ & $186.72 \pm 31.47$ & $173.92 \pm 62.08$ \\
\hline $\mathrm{Pb}$ & $3.56 \pm 2.98$ & $1.98 \pm 1.29$ & $1.91 \pm 1.68$ & $2.54 \pm 1.76$ & $2.84 \pm 2.04$ & $0.64 \pm 0.63$ \\
\hline $\mathrm{Sr}$ & $122.26 \pm 37.14$ & $152.62 \pm 43.50$ & $126.94 \pm 14.75$ & $127.06 \pm 19.28$ & $170.88 \pm 47.19$ & $157.48 \pm 41.85$ \\
\hline $\mathrm{Al}$ & $2041.40 \pm 543.52$ & $2463.00 \pm 572.29$ & $1714.00 \pm 384.86$ & $1925.60 \pm 396.65$ & $2520.80 \pm 417.18$ & $2271.00 \pm 810.66$ \\
\hline $\mathrm{Ba}$ & $20.68 \pm 1.54$ & $23.85 \pm 2.59$ & $18.55 \pm 2.60$ & $23.00 \pm 7.24$ & $24.95 \pm 2.93$ & $23.16 \pm 4.26$ \\
\hline $\mathrm{Cd}$ & $1.80 \pm 0.54$ & $2.20 \pm 0.51$ & $1.28 \pm 0.36$ & $1.61 \pm 0.53$ & $2.06 \pm 0.40$ & $1.98 \pm 0.75$ \\
\hline Co & $7.97 \pm 1.92$ & $9.98 \pm 1.81$ & $6.09 \pm 1.40$ & $7.09 \pm 1.73$ & $9.14 \pm 1.61$ & $8.23 \pm 2.70$ \\
\hline $\mathrm{Cr}$ & $41.51 \pm 12.72$ & $48.39 \pm 7.40$ & $31.57 \pm 6.25$ & $37.77 \pm 10.34$ & $46.17 \pm 8.45$ & $44.84 \pm 15.56$ \\
\hline $\mathrm{Se}$ & $0.00 \pm 0.00$ & $0.00 \pm 0.00$ & $0.00 \pm 0.00$ & $0.00 \pm 0.00$ & $0.00 \pm 0.00$ & $0.00 \pm 0.00$ \\
\hline
\end{tabular}

Data are averages of five replicates, with SD values $(n=5)$. ADF, acid detergent fiber; NDF, neutral detergent fiber

Table 5: Fiber, protein, macro and secondary elements present in shoot

\begin{tabular}{|c|c|c|c|c|c|c|}
\hline \multirow[t]{2}{*}{ Parameters } & \multicolumn{6}{|c|}{ Plant shoot sample } \\
\hline & CV1 & CV2 & TIVI & T1 V2 & T2V1 & $\mathrm{T} 2 \mathrm{~V} 2$ \\
\hline N.D.F & $52.29 \pm 13.42$ & $60.76 \pm 2.32$ & $60.46 \pm 3.80$ & $59.94 \pm 2.52$ & $59.36 \pm 2.01$ & $60.69 \pm 1.01$ \\
\hline A.D.F & $32.92 \pm 8.04$ & $40.02 \pm 2.75$ & $31.10 \pm 5.54$ & $33.62 \pm 5.08$ & $39.82 \pm 2.00$ & $40.49 \pm 1.46$ \\
\hline Crude Protein\%" & $9.14 \pm 1.58$ & $9.75 \pm 1.28$ & $8.78 \pm 1.30$ & $9.69 \pm 1.76$ & $7.55 \pm 1.67$ & $8.34 \pm 1.89$ \\
\hline $\mathrm{N}$ & $1.46 \pm 0.25$ & $1.56 \pm 0.20$ & $1.40 \pm 0.21$ & $1.55 \pm 0.28$ & $1.21 \pm 0.27$ & $1.33 \pm 0.30$ \\
\hline$P$ & $0.27 \pm 0.03$ & $0.29 \pm 0.02$ & $0.32 \pm 0.05$ & $0.30 \pm 0.08$ & $0.28 \pm 0.03$ & $0.28 \pm 0.04$ \\
\hline k & $1.42 \pm 0.08$ & $1.40 \pm 0.14$ & $1.44 \pm 0.09$ & $1.36 \pm 0.18$ & $1.59 \pm 0.27$ & $1.51 \pm 0.22$ \\
\hline $\mathrm{Ca}$ & $0.23 \pm 0.01$ & $0.24 \pm 0.02$ & $0.27 \pm 0.07$ & $0.23 \pm 0.03$ & $0.26 \pm 0.03$ & $0.26 \pm 0.07$ \\
\hline $\mathrm{Mg}$ & $0.14 \pm 0.01$ & $0.14 \pm 0.01$ & $0.20 \pm 0.04$ & $0.19 \pm 0.02$ & $0.15 \pm 0.01$ & $0.16 \pm 0.02$ \\
\hline S & $0.15 \pm 0.02$ & $0.16 \pm 0.03$ & $0.23 \pm 0.07$ & $0.23 \pm 0.03$ & $0.23 \pm 0.04$ & $0.20 \pm 0.01$ \\
\hline $\mathrm{Na}$ & $0.02 \pm 0.04$ & $0.02 \pm 0.04$ & $0.28 \pm 0.16$ & $0.48 \pm 0.13$ & $0.05 \pm 0.01$ & $0.10 \pm 0.12$ \\
\hline $\mathrm{Fe}$ & $143.85 \pm 21.38$ & $146.35 \pm 12.58$ & $149.48 \pm 43.92$ & $136.20 \pm 22.53$ & $185.00 \pm 51.77$ & $155.20 \pm 65.67$ \\
\hline $\mathrm{Cu}$ & $2.85 \pm 0.35$ & $2.66 \pm 0.31$ & $1.84 \pm 0.35$ & $1.75 \pm 0.40$ & $2.48 \pm 0.56$ & $1.98 \pm 0.59$ \\
\hline $\mathrm{Mn}$ & $9.95 \pm 3.84$ & $9.60 \pm 2.80$ & $11.74 \pm 1.04$ & $10.57 \pm 1.77$ & $10.78 \pm 4.18$ & $9.50 \pm 4.41$ \\
\hline $\mathrm{Zn}$ & $28.18 \pm 3.62$ & $27.26 \pm 4.03$ & $35.30 \pm 3.83$ & $34.24 \pm 8.87$ & $40.36 \pm 8.55$ & $30.74 \pm 5.57$ \\
\hline B & $32.44 \pm 5.60$ & $35.42 \pm 4.87$ & $32.67 \pm 5.73$ & $40.33 \pm 6.03$ & $40.20 \pm 9.93$ & $33.48 \pm 3.00$ \\
\hline Mo & $0.73 \pm 1.03$ & $0.94 \pm 1.40$ & $2.70 \pm 1.29$ & $2.51 \pm 0.67$ & $0.77 \pm 1.16$ & $1.18 \pm 0.57$ \\
\hline $\mathrm{Ni}$ & $2.14 \pm 1.02$ & $1.60 \pm 0.57$ & $2.23 \pm 0.83$ & $1.64 \pm 1.35$ & $2.94 \pm 1.26$ & $2.18 \pm 1.27$ \\
\hline $\mathrm{Pb}$ & $2.36 \pm 1.44$ & $0.92 \pm 0.88$ & $1.86 \pm 1.38$ & $1.96 \pm 1.70$ & $1.24 \pm 1.35$ & $0.48 \pm 0.57$ \\
\hline $\mathrm{Sr}$ & $35.59 \pm 1.96$ & $37.80 \pm 3.27$ & $36.62 \pm 6.27$ & $33.16 \pm 4.52$ & $37.70 \pm 6.55$ & $42.48 \pm 6.36$ \\
\hline $\mathrm{Al}$ & $74.84 \pm 16.92$ & $69.39 \pm 7.61$ & $65.47 \pm 24.77$ & $62.55 \pm 12.18$ & $95.00 \pm 17.82$ & $75.20 \pm 36.13$ \\
\hline $\mathrm{Ba}$ & $16.91 \pm 2.06$ & $15.40 \pm 1.23$ & $13.20 \pm 2.87$ & $9.43 \pm 1.05$ & $17.55 \pm 1.93$ & $16.29 \pm 3.07$ \\
\hline $\mathrm{Cd}$ & $0.00 \pm 0.00$ & $0.00 \pm 0.00$ & $0.00 \pm 0.00$ & $0.00 \pm 0.00$ & $0.00 \pm 0.00$ & $0.00 \pm 0.00$ \\
\hline Co & $0.15 \pm 0.17$ & $0.29 \pm 0.13$ & $0.19 \pm 0.11$ & $0.19 \pm 0.18$ & $0.21 \pm 0.21$ & $0.18 \pm 0.17$ \\
\hline $\mathrm{Cr}$ & $1.33 \pm 0.30$ & $1.47 \pm 0.28$ & $0.93 \pm 0.21$ & $1.04 \pm 0.51$ & $2.13 \pm 0.90$ & $1.25 \pm 0.53$ \\
\hline Se & $0.00 \pm 0.00$ & $0.00 \pm 0.00$ & $0.00 \pm 0.00$ & $0.00 \pm 0.00$ & $0.00 \pm 0.00$ & $0.00 \pm 0.00$ \\
\hline
\end{tabular}

Data are averages of fivereplicates, with SD values $(n=5)$. ADF, acid detergent fiber; NDF, neutral detergent fiber

per cent [23] and Atef Hamdy, 2002). Sodium and potassium are major cations of both intracellular and extracellular nature. Sodium is involved in controlling plasma volume, acid-base balance, contraction of the nerves and muscles.
Manganese is an antioxidant nutrient which is important for the breakdown of fats and cholesterol and also helps nervous and brain nourishment [24]. Magnesium deficiency may be responsible for tetany, tuberculosis, diabetes, cancer and all 
nerve diseases [25]. Zinc is a part of many metalloenzymes and is used as an astringent and antifungal agent in its organic compounds. Helps wound healing and nucleic acid and insulin metabolism. Zinc in excess induces anemia, which can lead to dermatitis if deficient in the body. The zinc level per $10 \mathrm{~g}$ of plant species was no greater than $4950 \mu \mathrm{g}$, thus lower than the maximum permissible amount and considered healthy [26].

Wastewater irrigation can have no major effect on soil heavy metals such as $\mathrm{Pb}$ and $\mathrm{Cd}$ regardless of irrigation period [27]. In plants which were grown in waste irrigation, the essential nutrients of plants such as $\mathrm{N}, \mathrm{NO}_{3}, \mathrm{P}$, and $\mathrm{K}$ are higher. However, the plant's $\mathrm{Pb}$ and $\mathrm{Cd}$ can increase if the irrigation time is two years, whereas they can decrease over a longer period. The presence of metals in wastewater may have an adverse effect on the nutritional value of the crops other than on the environment. It is found that in many cases the treatment plants do not extract the chemicals and metals adequately from the wastewater and thus adequate controls should be developed for removal processes [28], and the treated water should be used for agricultural purposes.

\section{CONCLUSION}

It has been concluded that there is significant variation in the macro-and micronutrient quality of wheat crops and cultivars. The levels of $\mathrm{Ca}, \mathrm{Mg}, \mathrm{Na}$, and $\mathrm{CI}$ in soil have increased significantly after irrigation, regardless of depth, when irrigated with managed water. However, the presence of cations and anions after irrigation with Abu Dhabi treated wastewater is slightly higher compared to before irrigation, although statistically no significant. In the case of $\mathrm{Al}$ Ain, $\mathrm{Ca}, \mathrm{Na}, \mathrm{CI}$ and $\mathrm{SO} 4$ after irrigation are significantly higher. With reference to the chemical composition of plants present in the head, root and shoot of wheat plants, the percentages of ND fiber, AD fiber, crude protein, Macro and Sec elements showed no major variations across the three locations and two varieties of wheat as evidenced by ANOVA test results. The chemical composition of treated wastewater concluded that there is a clear correlation between controlled water and treated $\mathrm{Al}$ Ain wastewater while the correlation between the treated $\mathrm{Al}$ Ain wastewater and Abu Dhabi wastewater is moderate. It is important to note that the associations between RBS limits and the three water types are negative. ANOVA findings indicate that the differences between the RBS maximum, regulated, treated Abu Dhabi wastewater and treated Al Ain wastewater are statistically important in terms of trace and heavy metals. The usage of wastewater would lead to substantial improvements in both grain production and biomass production.

\section{REFERENCES}

1. WWAP (United Nations World Water Assessment Programme), The United Nations World Water Development Report 2015: Water for a Sustainable World. Paris, UNESCO. 2015.

2. Garcia X, Pargament D. Reusing wastewater to cope with water scarcity: Economic, social and environmental conside1992 rations for decision-making. Resources, Conservation and Recycling. 2015; 101:154-166.

3. WWAP (United Nations World Water Assessment Programme), The United Nations World Water Development Report 2017. Wastewater: The Untapped Resource. Paris, UNESCO. 2017.
4. International Center for Biosaline Agriculture (ICBA, The Use of Treated Wastewater in the Agricultural Production in the Arab World: Current Status and Future Prospective, Dubai, United Arab Emirates. 2014; 1-40.

5. Qadir M, Bahri A, Sato T, Al-Karadsheh E. Wastewater production, treatment, and irrigation in Middle East and North Africa, Irrigation and Drainage Systems. 2010; 24: 37-51.

6. Chen W, Lu S, W Jiao, Wang M, Chang AC. Reclaimed water: A safe irrigation water source? Environmental Development. 2013; 8: 74-83.

7. Latimer GW. Official Methods of Analysis of AOAC International; AOAC International: Gaithersburg, MD, USA. 2016.

8. Waldern DE. A rapid micro-digestion procedure for neutral and acid detergent fiber. Canadian Journal of Animal Science. 1971; 51:67-9.

9. Dong FM, Rasco BA. The neutral detergent fiber, acid detergent fiber, crude fiber, and lignin contents of distillers' dried grains with solubles. Journal of Food Science. 1987; 52: 403-5.

10. Sample digestion methods. Sample digestion methods: Microwave assisted digestion of aqueous samples and extracts (Method 3015A), EPA Test Methods Online (SW-846). www.epa.gov/epawaste/hazard/ testmethods/sw846/pdfs/3015a.pdf. 2008.

11. Setterdahl AT, Chivers PT, Hirasawa M, Lemaire SD, Keryer E, MiginiacMaslow M, Kim SK, Mason J, Jacquot JP, Longbine CC, de LamotteGuery F. Effect of $\mathrm{pH}$ on the Oxidation- Reduction Properties of Thioredoxins. Biochemistry. 2003; 42:14877-84.

12. FAO. Irrigation and Drainage Paper. 1992; 48: 133

13. Bedbabis S, Trigui D, Ahmed CB, Clodoveo ML, Camposeo S, Vivaldi GA, Rouina BB. Long-terms effects of irrigation with treated municipal wastewater on soil, yield and olive oil quality. Agricultural Water Management. 2015; 160:14-21.

14. Wilcox L. Classification and use of irrigation waters. US Department of Agriculture; 1955.

15. Baas R, Berg D. Sodium accumulation and nutrient discharge in recirculation systems: a case study with roses. In III International Workshop on Models for Plant Growth and Control of the Shoot and Root Environments in Greenhouses. 1999; 507: 157-164.

16. Unkovich M, Stevens D, Ying GG, Kelly J. Impacts on crop quality from irrigation with water reclaimed from sewage.2004.

17. Silberbush M, Ben-Asher J, Ephrath JE. A model for nutrient and water flow and their uptake by plants grown in a soilless culture. Plant and soil. 2005; 271: 309-19.

18. Abbasian A, Ahmadi A, Abbasi AR, Darvishi B. Effect of various phosphorus and calcium concentrations on potato seed tuber production. Journal of Plant Nutrition. 2018; 41:1765-77.

19. Deniz S, Nursoy H, Ydmaz Y, Karsli MA. Effect of harvesting corn varieties at variying maturities on silage quality and digestible dry matter yield of corn silages. Veteriner Bilimleri Dergisi'nde. 2001; 17: 43-49.

20. Jones MM. Chemistry and society. Saunders College Publishing 1987

21. Pamela C, Richard A, Denise R. Metabolic effects of insulin and glucagon In: Lippincotts illustrated reviews: Biochemistery. $3^{\text {rd }}$. A wolters Kluwer company. Philadelphia, Baltemore, New York, London, Buenos Aires, Hong Kong, Sydney, Tokyo, 2005; 312.

22. Lavhale MS, Mishra SH. Nutritional and therapeutic potential of Ailanthus excelsa-A Review. Pharmacognosy Reviews. 2007; 1: 106-116.

23. Choukr-Allah R, Hamdy A. Reuse of treated wastewater for irrigation of cereals, forage and vegetables by means of different irrigation methods, European Commission (DGI) - CIHEAM-IAMB. 2002; 5 : $1-33$.

24. Chaturvedi UC, Shrivastava R, Upreti RK. Viral infections and trace elements: a complex interaction. Current Science. 2004; 87: 1536-54.

25. Claude B, Paule S. The manual of natural living. Biddles Limited Guildford Surrey. 1979; 98-99.

26. Annan K, Kojo Al, Cindy A, Samuel AN, Tunkumgnen BM. Profile of heavy metals in some medicinal plants from Ghana commonly used as components of herbal formulations. Pharmacognosy research. 2010; $2: 41$.

27. Munir J. Mohammad R, Sami H, Laith R. Long term effect of wastewater irrigation of forage crops on soil and plant quality parameters. Desalination. 2007; 215: 143-152.

28. Margot J, Rossi L, Barry DA, Holliger C. A review of the fate of micropollutants in wastewater treatment plants. Wiley Interdisciplinary Reviews: Water. 2015; 2: 457-487. 